\title{
DURKHEIM AND THE STUDY OF SUICIDE
}




\section{Durkheim and the Study of Suicide}

Steve Taylor

Macmillan Education 
ISBN 978-0-333-28646-3 ISBN 978-1-349-16792-0 (eBook)

DOI 10.1007/978-1-349-16792-0

(C) Steve Taylor 1982

Softcover reprint of the hardcover 1st edition 1982 978-0-333-28645-6

All rights reserved. For information, write:

St. Martin's Press, Inc., 175 Fifth Avenue, New York, NY 10010

First published in the United States of America in 1982

ISBN 978-0-312-22266-6

\section{Library of Congress Cataloging in Publication Data}

Taylor, Steve.

Durkheim and the study of suicide.

1. Suicide-Research. 2. Suicide-Psychological

aspects. 3. Durkheim, Emile, 1858-1917. Le suicide.

I. Title.

HV6545. T36 $1982 \quad 394^{\prime} 8 \quad 82-6001$

ISBN 978-0-312-22266-6

AACR2 
To Clive Ashworth, Olive Banks and Eric Dunning 


\section{Contents}

Preface ix

Acknowledgement x

Introduction $\quad \mathrm{xi}$

PART I EXPLAINING THE SUICIDE RATE

1 Durkheim's Suicide 3

2 The Sociologistic Perspective on Suicide 22

PART II THE SOCIAL CONSTRUCTION OF OFFICIAL SUICIDE RATES

3 Some Critiques of Official Suicide Rates 43

4 Proving Suicide 65

5 Persons under Trains 95

PART III THE SOCIAL CONTEXT OF SUICIDAL ACTIONS

6 Individualistic Approaches to Suicide 125

7 Suicide and the Gamble with Death 140

8 The Ordeal and the Sacrifice 161

General Conclusions $\quad 194$

$\begin{array}{ll}\text { Postscript } & 197\end{array}$

Appendix: 'Persons under Trains' 1975

Notes and References $\quad 202$

Bibliography 236

Index 245 


\section{Preface}

I should like to express my gratitude to all the officials who agreed to talk to me about their work; London Transport for their cooperation in part of this research; the Lanchester Polytechnic, Coventry, for financial assistance with part of the study; a number of people, including Peter Baehr, Alf Barrett, Stan Cohen, Nick Tilley and Jock Young, who have been kind enough to comment on parts of the text; Anne Southall, who assisted with some of the fieldwork; and Anthony Giddens, who was a most helpful and encouraging editor. My greatest debt is to Clive Ashworth of Leicester University - without his painstaking help and keen critical intelligence this work would not have been written. The errors and shortcomings that remain are, of course, Durkheim's.

Steve Taylor 


\section{Acknowledgement}

The author and publishers are grateful to Olwyn Hughes on behalf of Ted Hughes, and Harper \& Row, Publishers, Inc., for permission to quote an extract from 'Lady Lazarus' in Ariel by Sylvia Plath. Copyright (C) 1965 by Ted Hughes. 


\section{Introduction}

My interest in suicide, which stemmed from a long-held fascination with 'daredevil' and risk-taking behaviour, was stimulated by the work of the late Erwin Stengel, who was the first to show that most serious suicidal acts, including many that actually end in death, are in fact risk-taking exercises and, in this respect, may be usefully likened to medieval ordeals. From this point of view the problem for suicide research is not so much why people put a determined end to their lives as why many more gamble with death and allow fate to decide whether or not they go on living.

The traditional sociological approach to suicide involving the explanation of comparative suicide rates, which I discuss in Part I of the book, seemed to me to have two important deficiencies. First, a relatively uncritical reliance on official suicide rates, and second, a lack of interest in studying what may be termed the micro-social contexts of suicidal acts which led students to misunderstand the nature of suicide, especially its risk-taking dimension. The research undertaken for this book is devoted to the examination of these two problems.

Part II examines the production of official suicide statistics where I attempt to develop the excellent critiques advanced by Douglas and Atkinson into a demonstration of the dangers of the use of such data for research purposes.

Part III discusses more 'individually orientated' approaches to suicide, documents and attempts to explain the risk-taking nature of certain suicidal acts, and concludes with the development of an alternative social-psychological approach to suicide.

At each stage of the work I have tried to relate specific debates and issues in suicide research to the more general debates within the 
social sciences. In this context Durkheim's work remains a massive influence, for, despite a tendency in recent work to caricature Durkheim as responsible for anything that seems 'bad' in modern social science, for example 'conservatism', 'functionalism', 'positivism' or 'anti-psychological social determinism', he remains the most difficult of all the leading figures in the social sciences to 'pigeonhole'. In fact, I shall try to show how modern students of suicide have not so much 'progressed beyond' Durkheim, as they often like to believe, but rather, by returning to one or other of the horns of the philosophical dilemmas that Durkheim tried to synthesise, they have returned research conceptually to the state it was in prior to Suicide. Indeed, seen from a Durkheimian perspective, the respective parties of many of the most intense debates in the social sciences, for example between 'social' or 'individual' explanations or positivist $v s$ interpretative methods, are united by far more than separates them, in particular a shared positivist view of natural science and a common commitment to an empiricist epistemology.

In Chapter 1, I differentiate Durkheim's approach to suicide from those adopted by later students and, in the final chapter, despite significant reservations about Durkheim's theory of suicide, I draw upon many of his most important insights to develop an alternative, structural, theory of suicide.

While suicide appears to be a topic of great interest to both 'lay' and 'professional' people, at present there are relatively few sociologists working in this field. Therefore, I have tried to write a text which will be of interest to those whose main concern is either with suicide research or sociological research. 